$\overline{\text { ノー }}$

[Nippon Nögeikagaku Kaishi

Vol. 62, No. 1, pp. 31 33, 1988]

\section{Brevibacterium ammoniagenes $の$}

変異株によるウラシルの蓄積†

小林節子，荒木和美，中山、清*

（協和醗酵工業株式会社東京研究所，

*現在,バイオール株式会社座間研究所)

昭 和 62 年 8 月 28 日受理

\section{Uracil-Producing Mutants of \\ Brevibacterium ammoniagenes}

Setsuko KOBAYASHI, Kazumi ARAKI and Kiyoshi NAKAYAMA*

Tokyo Research Laboratory, Kyowa

Hakko Co., Machida, Tokyo 194

* Zama Research Laboratory, Biol Co., Zama 228

A 2-fluoroadenine resistant derivative of $B$. ammoniagenes ATCC 6872 (wild-type strain) was found to accumulate a large amount of uracil in the culture medium. The concentration of accumulated uracil reached $3.9 \mathrm{mg} / \mathrm{ml}$ with a medium containing $11.25 \%$ (as sugar concentration) cane molasses and $3.75 \%$ glucose. Adenine accumulated at less than $0.5 \mathrm{~kg} / \mathrm{ml}$.

(Received August 28, 1987)

ウラシル系物質が他の核酸成分とともに微生物の培養

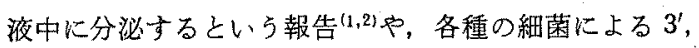
5'ーサイクリックロリジル酸の製法特許 ${ }^{(3)}$ が知られてい る. また，大腸菌 ${ }^{(4)}$ Brevibacterium ammoniagenes ${ }^{(5)}$ の野生株を，6ーブザウラシルを含む培地で培養すると， ウリジル酸が蓄積することが知られている。これらの場 合, 培地に涯加した 6-アザウランルの代謝生成物がピ リミジン生合成の代謝制御に影響を与えて，ウリジル酸 の過剩の蓄積を誘発したものと考えられる.ささらに， $B$. ammoniagenes $^{(5)}$ で，培地にオロット酸を添加すると

†本報の概略は, U.S.-Japan Intersociety Microbiology Congress (Los Angeles-Honolulu, May, 1979）で発表した.
にぼ定量的にウリジル酸へ転換して蓄皘することが知ら れている。

変暴株を用いる、いわゆる直接発醏によるウラシル系 化合物の著量の蓄積については，最近Bacillus 属細菌の ウリジンヌクレオチドホスホリラーゼ欠失変異株から誘 導したピリミジンアナログ耐性株によるウリジンの製法 が特許出願されている(6).

著者ら(7)は先に, B. ammoniagenes の2-フルオロ?デ ニン（FA）耐性株が著量のアデニンを蓄樍することを 報告したが，このよらな変異株のなかに未知の紫外線吸 収物質を蓄積する变異株 BF-93 を見出した，BF-93の 発酵液を, イソ酪酸: $0.5 \mathrm{~N}$ アンモニア $(10: 6)$ の溶媒 系を用いる薄層クロマトグラフィーで展開後, この未知 物質相当部分を分取し，熱水で抽出して調製したすのを 試料として, Table I K示す 9 種の展開溶媒でペーパー クロマトダラフィーを行ったところ，そのRf 值は，標 準ウランルのそれとよく一致した，菓た，Table I の溶 媒系のBと F, G と H, H とJを使用した 2 次宇ぺーパ ークロマトグラフィーでの挙動も標準ウラシルとよく一 致した.さらに，紫外部吸収曲線 (Fig. 1) む標準ウラン ルのそれとよく一致した．以上の結果から，この未知物

Table I. Paperchromatographic Identification of Uracil Produced by B. ammoniagenes BF-93

\begin{tabular}{ccc}
\hline \multirow{2}{*}{ Solvent system } & \multicolumn{2}{c}{$R f$-value } \\
\cline { 2 - 3 } Sample & Authentic urecil \\
\hline A & 0.55 & 0.57 \\
B & 0.53 & 0.54 \\
C & 0.53 & 0.54 \\
D & 0.55 & 0.56 \\
E & 0.21 & 0.20 \\
F & 0.76 & 0.76 \\
G & 0.64 & 0.68 \\
H & 0.47 & 0.47 \\
I & 0.79 & 0.79 \\
\hline
\end{tabular}

* Solvent system :

A, $n$-butanol-acetic acid- $\mathrm{H}_{2} \mathrm{O}=5: 2: 2 ; \mathrm{B}$, isobutyric acid-0.5 N. $\mathrm{NH}_{4} \mathrm{OH}=10: 6 ; \mathrm{C}, n$ propanol-0. $2 \mathrm{~N} \mathrm{NH}_{4} \mathrm{OH}=3: 1$; D, $n$-butanolacetone $-\mathrm{H}_{2} \mathrm{O}$-diethylamine $=10: 10: 5: 2 ; \mathrm{E}$, $n$-butanol- $\mathrm{H}_{2} \mathrm{O}$-conc. $\mathrm{NH}_{4} \mathrm{OH}=172: 18: 10 ; \mathrm{F}$, isopropanol- $\mathrm{H}_{2} \mathrm{O}$-conc. $\mathrm{HCl}=130: 37: 33 ; \mathrm{G}$, methanol-ethanol-conc. $\mathrm{HCl}-\mathrm{H}_{2} \mathrm{O}=50: 25: 6$ : $19 ; \mathrm{H}$, isobutyric acid-acetic acid-0. $5 \mathrm{~N} \mathrm{NH}_{4} \mathrm{OH}$ $=10: 1: 5 ; \mathrm{I}$, methanol-conc. $\mathrm{HCl}-\mathrm{H}_{2} \mathrm{O}=70$ : $20: 10$. 
質をウラシルと同定した。

BF-93 を用いて，ウラシルの蓄積条件を搝討した．培 地，培项条件等は先報 ${ }^{(8)}$ 亿準し，発醉培地 $20 \mathrm{ml}$ を含を バッフル板付きの $300 \mathrm{ml}$ 容三角フラスコを用いて行っ た. 発酵培地の炭素源としては，甘蔗廃桾篦（11.25\%， 糖濃度換算)とダルニース (3.75\%) の混合物を用い

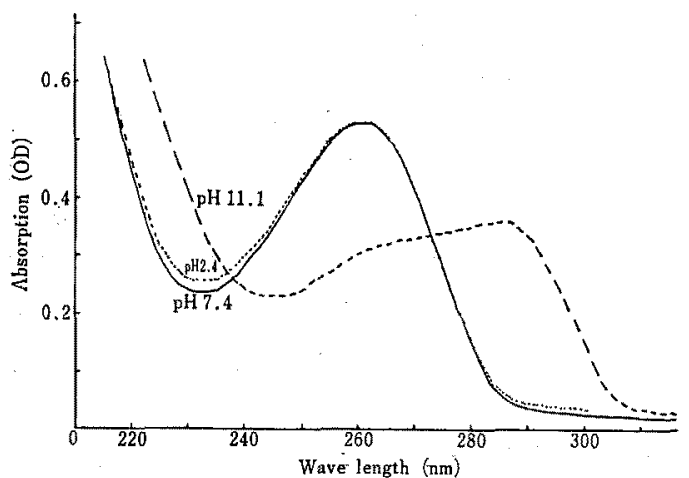

Fig. 1. UV-Absorption Curve of Uracil Produced by B. ammoniagenes BF-93.
た. 窒素源として $0.2 \%$ の尿素を含む発醅培地に, 種々 の天然栄養物, 無機窐素源を添加して，それらのウラシ 儿蓄積住対する効果を調べた．その結果，天然栄着物 (Fig. 2)のなかでは肉エキスと醉母エキスの添加が有效 であった. 肉エキス $1 \%$ 添加のとき $2.3 \mathrm{mg} / \mathrm{ml}$ のウラ シルが蓄積した：この時無添加の基本培地でのウラシル の蓄積量は $0.6 \mathrm{mg} / \mathrm{ml}$ であった、ペプトンやューン・ スチープ・リカーの添加はそれほど効果がなかった。次 に，無機空素源（Fig.3）としては，硫酸アンモニウム と塩化アンモニウムが有効であり，硫酸フンモニウム $2 \%$ (窒素として $0.5 \%$ ) 添加したとき $2.8 \mathrm{mg} / \mathrm{ml}$ のウ ラシルが蓄積した、いずれの場合もアデニンが副生産さ れたが，その蓄積量は $0.5 \mathrm{mg} / \mathrm{ml}$ 以下であった。

BF-93 は上述の上万に，きわめて再現性よく著量のウ ラシルを蓄積したが，これを殺菌水に愳濁希䣋して，保 存継代用スラント之同一組成の寒天平板（肉エキス 1 $\%$ ，ポリペプトン $1 \%$ ，醉母ェキス $0.5 \%, \quad \mathrm{NaCl} 0.25$ $\%, \mathrm{pH} 7,2)$ に塗珠して二ロニー状に生育させ、これを
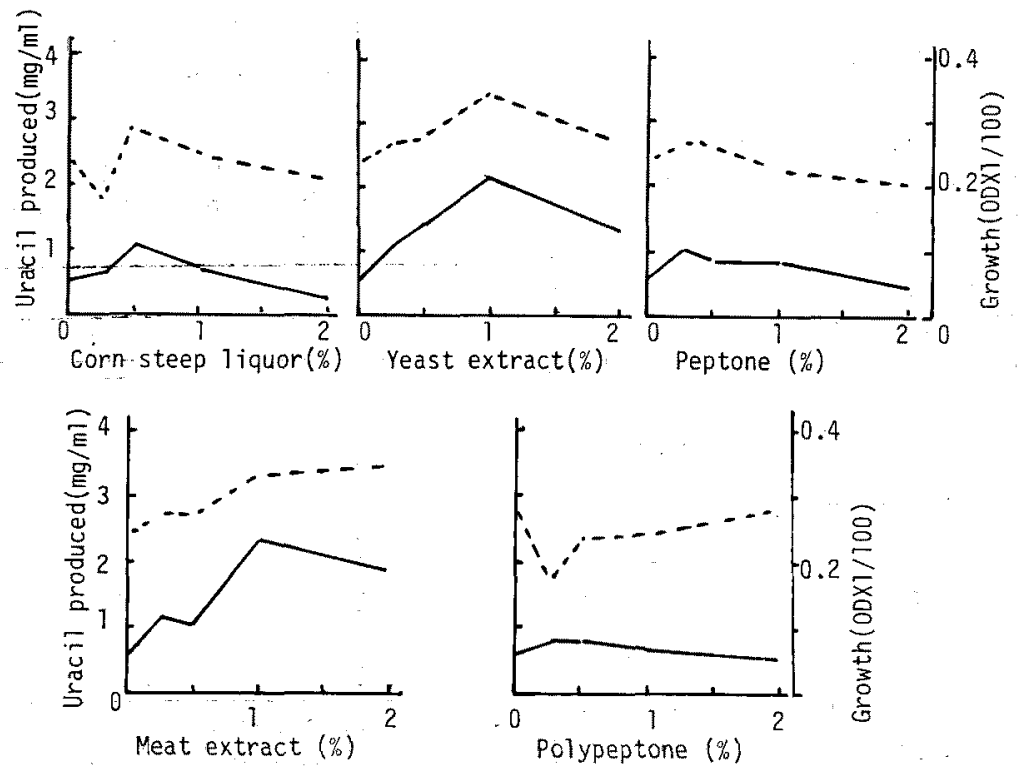

Fig. 2. Effect of Natural Nutrients on Uracil Production by B. ammoniagenes BF-93. -..., growth; - uracil. Fermentation was carried out in a $300-\mathrm{ml}$ Erlenmeyer flask containing $20 \mathrm{ml}$ of media which had the following basal components: 11.25\% (as sugar concentration) cane molasses, $3.75 \%$ glucose, $0.2 \%$ urea, $0.2 \% \quad \mathrm{KH}_{2} \mathrm{PO}_{4}, \quad 0.1 \%$ $\mathrm{K}_{2} \mathrm{HPO}_{4}, 0.001 \% \mathrm{FeSO}_{4} \cdot 7 \mathrm{H}_{2} \mathrm{O}, 0.001 \% \mathrm{MnSO}_{4} \cdot 4 \mathrm{H}_{2} \mathrm{O}, 0.05 \% \mathrm{MgSO}_{4} \cdot$ $7 \mathrm{H}_{2} \mathrm{O}$, thiamine $\mathrm{HCl} 2.5 \mathrm{mg} / l$, biotin $200 \mu \mathrm{g} / l, \beta$-alanine $100 \mu \mathrm{g} / \mathrm{l}$, Ca-pantothenate $10 \mathrm{mg} / \mathrm{l}$, L-cysteine. $\mathrm{HCl} 20 \mathrm{mg} / \mathrm{ml}, 3 \% \mathrm{CaCO}_{3}$. Refer to the earlier paper ${ }^{(8)}$ for the other details of the experiment. 

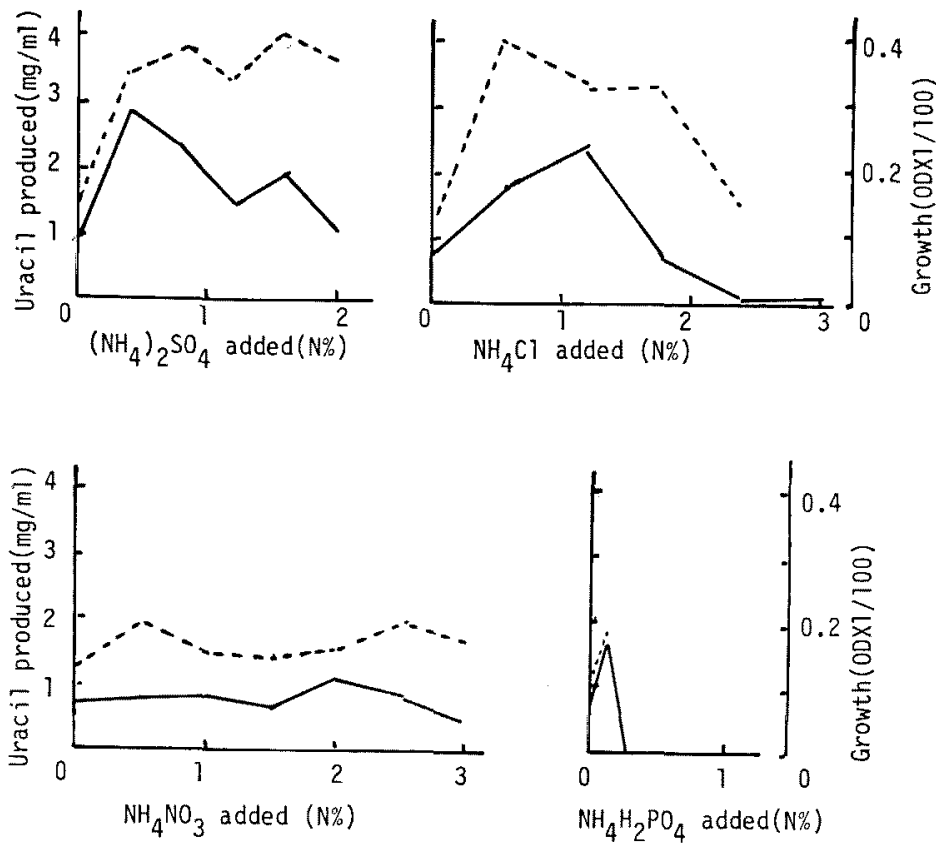

Fig. 3. Effect of Inorganic Nitrogen Sources on Uracil Production by B. ammoniagenes BF-93. For the details of the experiment, refer to the legend to Fig. 2.

釣菌して生産試験を行らと,たとえば 105 株の培䉥で, すべてがアデニンを蓄積するが，ウラシルを全く蓄積し ない現象を認めた。この際，対照として同様に培盖した BF-93 は正常にウラシルを蓄積した，そこで，殺菌水の 代りに，種培地で懸濁・希釉して上述と同様にモノコロ ニ一分離を行うと，B.ammoniagenes の通常の色調の二

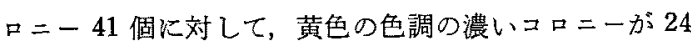
個発現した。この黄色の色調の濃い 24 菌株之, 通常の 色調のコロニーのうち 27 株とを, 登醉試験にかけたと ころ, 前者では 11 株が $2.6 \sim 3.9 \mathrm{mg} / \mathrm{ml}$ のウラシルを 蓄積したが，後者では全くウラシルの蓄積が認められな かった、最もウラシル蓄積量の高かった ISY-5 と名づ けた株ではウラシル $3.9 \mathrm{mg} / \mathrm{ml}$, アデニン $0.4 \mathrm{mg} / \mathrm{ml}$ 蓄積しだ.このとき対照とした BF-93 ではウラシル 2.3 $\mathrm{mg} / \mathrm{ml}$, アデニン $0.45 \mathrm{mg} / \mathrm{ml}$ を蓄䆊した.

BF-93 には，黄色の色調の濃いウラシル生産菌と，通 常の色調のアデニン生産菌が混在していて，殺菌水で懸 濁・希釈する操作の過程で，黄色のウラシル生産菌が死 減すると考えると上述の現象が理解できる。
このような FA 酎性の付与によって,アデニンととも にウラシルが蓄積する原因はわからないが，先報(8)て報 告したように，同じB.ammoniagenes のFA 酎性株で アデニンとともにシトシンの蓄積する現象が認められて いるので，FA 耐性の付与によって，何らかの機構でプ リンとピりミジンの両方の生合成が同時に促進されるも のと考えられる。

(1) T. Okabayashi : J. Bacteriol., 84, 1(1962).

(2) K. Ogata, A. Imada and Y. Nakao: Agric. Biol. Chem., 26, 586 (1962).

(3) 石山二郎：特開昭 50-18691.

(4) R.E. Hundschumacher : Nature, 182, 1090 (1958).

(5) K. Nakayama and H. Tanaka: Agric. Biol. Chem., 35, 518 (1971).

（6）常見 裕, 朝日 知, 土屋宗晴：特開昭 61104795.

（7）下条節子，荒木和美，中山 清：農化，48，63 (1974).

（8）小林節子，荒木和美，中山 清：農化，52，129 (1978). 